\title{
Granulomatosis-associated myositis
}

\author{
High prevalence of sporadic inclusion body myositis
}

Yannick Dieudonné, MD, Yves Allenbach, MD, PhD, Olivier Benveniste, MD, PhD, Sarah Leonard-Louis, MD, Baptiste Hervier, MD, PhD, Kuberaka Mariampillai, PhD, Benoit Nespola, PharmD, Béatrice Lannes, MD, PhD, Andoni Echaniz-Laguna, MD, PhD, Daniel Wendling, MD, PhD, Christian Von Frenckell, MD, PhD, Nicolas Poursac, MD, Emmanuel Mortier, MD, Christian Lavigne, MD, Olivier Hinschberger, MD, Julie Magnant, MD, Jacques-Eric Gottenberg, MD, PhD, Bernard Geny, MD, PhD, Jean Sibilia, MD, PhD, and Alain Meyer, MD, PhD

Neurology ${ }^{\circledR}$ 2019;00:1-11. doi:10.1212/WNL.0000000000008863

Abstract
Objective
To refine the predictive significance of muscle granuloma in patients with myositis.

\section{Methods}

A group of 23 patients with myositis and granuloma on muscle biopsy (granuloma-myositis) from 8 French and Belgian centers was analyzed and compared with (1) a group of 23 patients with myositis without identified granuloma (control-myositis) randomly sampled in each center and (2) a group of 20 patients with sporadic inclusion body myositis (sIBM) without identified granuloma (control-sIBM).

\section{Results}

All but 2 granuloma-myositis patients had extramuscular involvement, including signs common in sarcoidosis that were systematically absent in the control-myositis and the control-sIBM groups. Almost half of granuloma-myositis patients matched the diagnostic criteria for sIBM. In these patients, other than the granuloma, the characteristics of the myopathy and its nonresponse to treatment were similar to the control-sIBM patients. Aside from 1 patient with myositis overlapping with systemic sclerosis, the remaining granuloma-myositis patients did not match the criteria for a well-defined myositis subtype, suggesting pure sarcoidosis. Matching criteria for sIBM was the sole feature independently associated with nonresponse to myopathy treatment in patients with granuloma-myositis.

\section{Conclusion}

Patients with granuloma-myositis should be carefully screened for sIBM associated with sarcoidosis in order to best tailor their care.

\footnotetext{
From the Département d'Immunologie Clinique et Médecine Interne (Y.D.) and Département de Rhumatologie (J.-E.G., J.S., A.M.), Centre de Référence des Maladies Auto-immunes Rares, Département d'Immunobiologie (B.N.), Département de Pathologie (B.L.), Département de Neurologie, Centre de Référence des Maladies Neuro-musculaires (A.E.-L.), and Institut de Physiologie EA 3072, Service de Physiologie et d'Explorations Fonctionnelles (B.G., A.M.), Hôpitaux Universitaires de Strasbourg; Département de Médecine Interne et Immunologie Clinique (Y.A., O.B., B.H., K.M.), Centre de Référence des Maladies Neuro-Musculaires Paris Est, Assistance Publique-Hôpitaux de Paris (AP-HP), DHU I2B, Sorbonne Universités UPMC Univ Paris 06, Inserm, UMR 974, Centre de Recherche en Myologie, Hôpital Universitaire Pitié-Salpêtrière; Département de Neuropathologie (S.L.-L.), Centre de Référence des Maladies Neuro-Musculaires Paris Est, Hôpital Universitaire Pitié-Salpêtrière; Fédération de Médecine Translationnelle de Strasbourg (B.L., J.-E.G., B.G., J.S., A.M.), Université de Strasbourg; Département de Rhumatologie (D.W.), Hôpital Universitaire de Besançon, France; Département de Rhumatologie (C.V.F.), Hôpital Universitaire Sart-Tilman, Liège, Belgium; Departement de Rhumatologie (N.P.), Hôpital Universitaire de Bordeaux; Departement de Médicine Interne (E.M.), Hôpital Universitaire Louis Mourier, Colombes; Departement de Médicine Interne et Maladies Vasculaires (C.L.), Hôpital Universitaire d'Angers; Departement de Médicine Interne (O.H.), Hôpital Emile Muller, Mulhouse; Departement de Médicine Interne (I.M.), Hôpital Universitaire de Tours, France.

Go to Neurology.org/N for full disclosures. Funding information and disclosures deemed relevant by the authors, if any, are provided at the end of the article.
} 


\section{Glossary}

$\mathbf{C K}=$ creatine kinase $; \mathbf{D M}=$ dermatomyositis; $\mathbf{E N M C}=$ European Neuromuscular Centre; $\mathbf{E U L A R} / \mathbf{A C R}=$ European League Against Rheumatism/American College of Rheumatology; NAM = necrotizing autoimmune myopathy; $\mathbf{O M}=$ overlap myositis; $\mathbf{P M}=$ polymyositis; $\mathbf{s I B M}=$ sporadic inclusion body myositis.

Myositis encompasses a heterogeneous group of diseases, some of which have been defined on the basis of clinical, serologic, and histopathologic characteristics. These welldefined myositis subgroups include dermatomyositis (DM), overlap myositis $(\mathrm{OM})$, necrotizing autoimmune myopathy (NAM), polymyositis (PM), and sporadic inclusion body myositis (sIBM). ${ }^{1,2}$ Their identification is fundamental because each of these distinct disorders has a different prognosis as well as a different response to therapy. ${ }^{3}$

Noncaseating granulomas can be observed in different tissues in a wide range of diseases. The diagnosis of sarcoidosis is retained when no alternative cause is found. ${ }^{4}$ Patients with sarcoidosis frequently have muscle pain, exercise intolerance, and weakness ${ }^{5}$ that can result from high circulating levels of tumor necrosis factor- $\alpha$, corticosteroid treatments, or deconditioning. ${ }^{6}$ Only $0.5 \%-2.3 \%$ present evidence of myositis (muscle weakness, increased serum creatine kinase $[\mathrm{CK}]$ activity, myopathic changes on EMG, or histologic lesion of muscle fibers). ${ }^{7}$ Myositis response to immunomodulatory treatment in these patients has been reported to be unpredictable. ${ }^{8}$ Myopathy is considered as part of the clinical spectrum of sarcoidosis. ${ }^{4}$ However, in some patients, myopathy has been reported to be related to sIBM, which may be misdiagnosed as sarcoid myopathy, as described in case reports and short series ( $<4$ patients). ${ }^{9,10}$ Granuloma within the muscle has also been more rarely reported in other well-defined myositis cases. ${ }^{11}$ Because each of these conditions requires specifically tailored management, there is a need to refine the significance of granuloma in patients with myositis. This study was thus undertaken to identify homogeneous groups of patients with myositis with granuloma in muscle and to search for predictors of muscle response to treatment.

\section{Methods}

\section{Patients, study design, and data collection}

Patients were diagnosed with myositis if they met the 2017 European League Against Rheumatism/American College of Rheumatology (EULAR/ACR) diagnostic criteria. ${ }^{12}$ Patients were subsequently diagnosed with granuloma-myositis if they had myositis and (1) had undergone muscle biopsy with noncaseating granuloma (on pathology report description, verified by a second review of the pathology), defined as a compact circumscribed cluster of epithelioid and multinucleated histiocytes without necrosis as revealed by hematoxylin \& eosin staining; and (2) had no evidence of infection or primary immunodeficiency that might cause granuloma formation. ${ }^{4}$
Granuloma-myositis patients were first identified among the Strasbourg University Hospital cohort of 509 patients with myositis. All practitioners registered on MyositEst (a network for myositis in Eastern France), the Club Rhumatisme et Inflammation (a national network for rare autoimmune diseases), and the French myositis network were also contacted by electronic letters and asked to report their observations (a total of $\approx 1,500$ physicians).

Twenty-three patients with myositis without granuloma identified during the follow-up were randomly selected (no age or sex matching) in participating centers and included as controls (control-myositis group). An additional group of 20 patients matching 2017 EULAR/ACR criteria for myositis and subclassified as sIBM was also included (control-sIBM). The European Neuromuscular Centre (ENMC) $2013^{13}$ and Lloyd et al. ${ }^{14}$ criteria were used to confirm the diagnosis of sIBM, because these criteria have been shown to exhibit the best performance for the diagnosis of this disease.

For all patients, clinical, biological, and histologic data as well as treatments were systematically recorded using a standardized questionnaire. Dysphagia was defined as pharyngeal or esophageal signs when eating or drinking (e.g., difficulty swallowing solids or liquids, food sticking in throat, coughing while eating). ${ }^{15}$ The presence of anti-Jol and anti-U1-RNP was tested at time of diagnosis in all patients (EuroImmun, Lübeck, Germany; D-TEK, Mons, Belgium; or Alphadia, Wavre, Belgium, depending on the center). The presence of the following 18 additional autoantibodies specific to or associated with inflammatory myopathies was further tested in available sera: antiNT5c1A (EuroImmun); anti-HMGCR, anti-Mi2, anti-MDA5, anti-NXP2, anti-Tifanti- $1 \gamma$, anti-SAE (D-TEK); anti-SRP, antiPL7, anti-PL12, anti-EJ, anti-OJ, anti-KS, anti-Zo, anti-Ha, anti-Ku, anti-PM/Scl (Alphadia); and anti-AMA2 (Medical Diagnostic, La Verne, CA). Thereafter, patients were categorized as DM, OM, NAM, PM, or sIBM using available criteria. ${ }^{1,2}$ Patients who did not match the criteria for 1 of these myositis subtypes were recorded as "without categorizable myositis." Patients were classified as responders to myopathy treatment if they normalized their strength and CK activity or improved at least 1 full Medical Research Council grade in 2 proximal and 2 distal muscles in the arms and legs if they did not normalize. Patients were otherwise classified as nonresponders.

\section{Standard protocol approvals, registrations, and patient consents}

This study was approved by the ethics committee of the Strasbourg University Hospital (no. 2017-55). 


\section{Statistical analysis}

Data are presented as median (range) or frequency (\%) with $95 \%$ confidence intervals. Continuous variables were analyzed using 2-tailed Mann-Whitney $U$ test (for 2-group comparisons) or Kruskal-Wallis test (for multiple groups comparisons). Categorical variables were compared using Fisher exact test. Statistical significance was defined as $p<0.05$. Multivariate analysis using ridge logistic regression was used for factors with a $p$ value $<0.10$ in univariate analysis in order to identify predictable factors of muscle response to treatment. Agreement was assessed with Cohen $\kappa$. Statistical analyses were performed using GraphPad PRISM V.5 and JMP 7.0.

\section{Data availability}

Anonymized data not published within the article will be shared upon request from any qualified investigator.

\section{Results}

Twenty-six patients with myositis with granuloma were studied. Three patients were excluded due to uncertain granuloma $(\mathrm{n}=1)$, insufficient available clinical data $(\mathrm{n}=1)$, and alternative cause for granuloma $(\mathrm{n}=1$; disseminated bacillus Calmette-Guérin disease). Thus 23 patients with myositis and granuloma (granuloma-myositis) were included (figure 1). The female/male ratio was $0.8(10 / 13)$, age at myositis diagnosis was 60 years (range 28-81), and follow-up was 46 months (range 2-457).

\section{Granuloma-myositis patients feature systemic signs of granulomatosis}

Extramuscular granulomas were found in $52 \%$ of patients between 120 months before and 40 months after myositis diagnosis (median delay 16 months before diagnosis). In 17\% of granuloma-myositis patients, granulomas were found in more than 2 organs.

Overall, extramuscular symptoms were reported in all but 2 patients with granuloma vs $86 \%$ in the control-myositis group $(p=1.0)$. Granuloma-myositis patients had 10-fold more frequent nodes than control-myositis patients $(39 \%$ vs $4 \%$ $p=0.01)$ and one third presented sarcoid-like extramuscular signs that were otherwise systematically absent in the controlmyositis group, namely cutaneous sarcoidosis $(n=2)$, erythema nodosum $(n=2)$, granulomatous hepatitis $(n=2)$, tubuleinterstitial nephropathy $(\mathrm{n}=2)$, and anterior uveitis $(\mathrm{n}=1)$. In addition, $48 \%$ of the granuloma-myositis patients presented biological signs of granulomatosis (i.e., hypercalcemia or increased angiotensin-converting enzyme) vs none in the controlmyositis group $(p=0.0002)$.

\section{Almost half of patients with myositis with granuloma matched the criteria for SIBM and did not respond to treatment}

A total of 10 (43\%) granuloma-myositis patients matched the ENMC criteria for sIBM, ${ }^{12}$ which was higher compared to the control-myositis group. sIBM diagnosis was clinicopathologically defined $(n=4)$, clinically defined $(n=4)$, and probable $(\mathrm{n}=2)$. Representative muscle pathologic findings are shown in figure 2 .

Comparison among (1) granuloma-myositis patients matching ENMC criteria for $\operatorname{sIBM}(\mathrm{n}=10),(2)$ the remaining patients of the granuloma-myositis group $(\mathrm{n}=13)$, and (3) the sIBM control group $(n=20)$ is shown in table 1 . In accordance with sIBM diagnosis, patients with myositis with granuloma matching ENMC diagnostic criteria for this disease were more frequently men (F/M ratio: $4 / 6)$, with a 31month (range 12-240) delay between weakness onset and

Figure 1 Patient inclusion

Patients with myositis

(Strasbourg University Hospital Centre)

$(\mathrm{N}=509$; patients with myositis and granuloma $[n=4])$

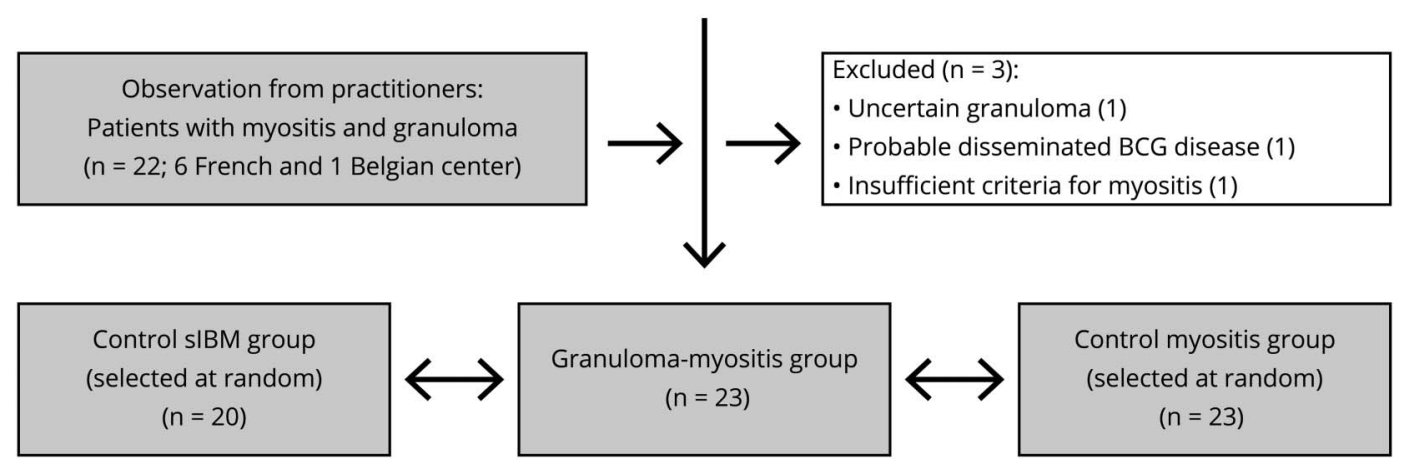

BCG = bacillus Calmette-Guérin; sIBM = sporadic inclusion body myositis. 
Figure 2 Representative histologic, histochemical, and immunohistochemical findings in muscle tissue of granuloma-myositis patients
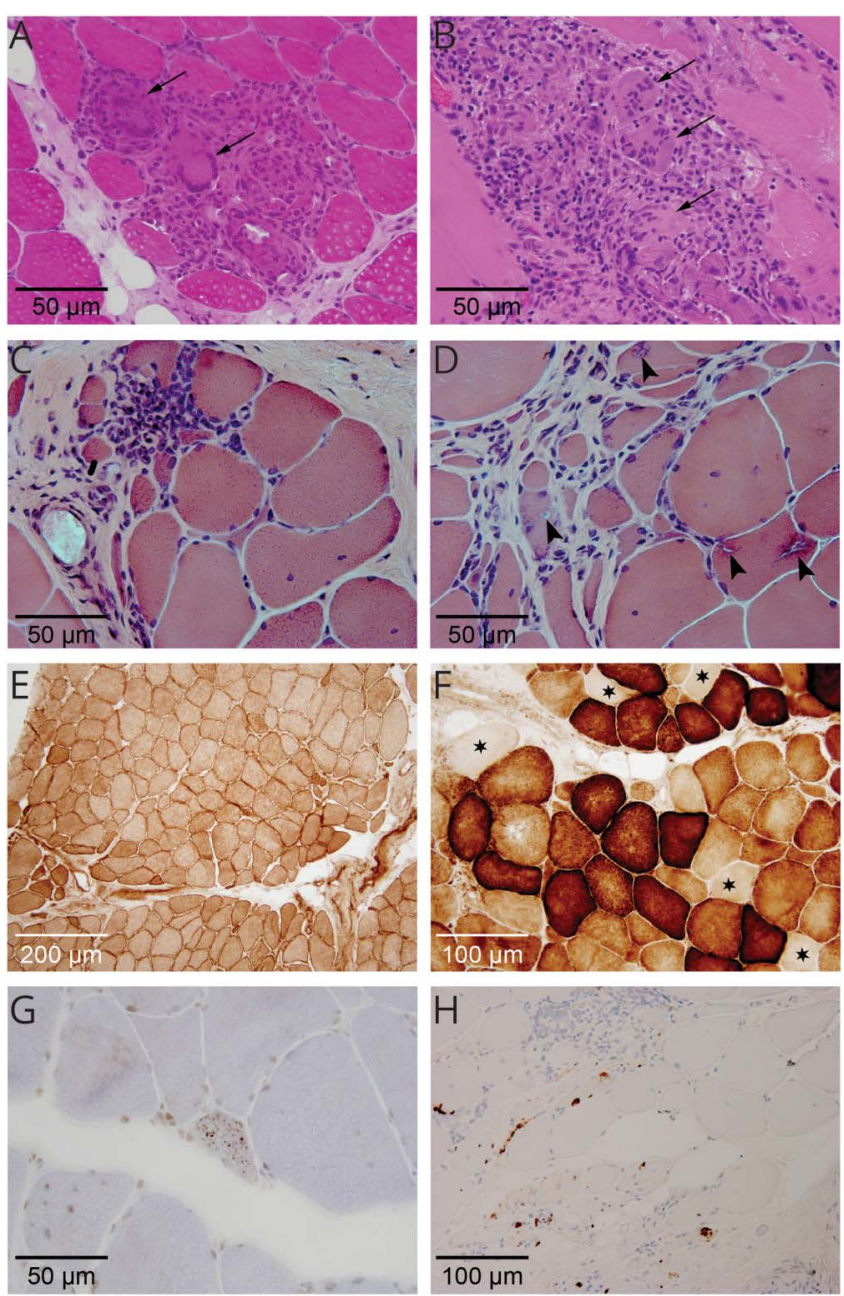

Hematoxylin \& eosin (H\&E) staining in paraffin-embedded sections shows endomysial noncaseating granuloma in a patient who did not match $(A)$ and a patient who matched (B) European Neuromuscular Centre (ENMC) criteria for sporadic inclusion body myositis (SIBM): compact circumscribed cluster of epithelioid and multinucleated histiocytes (arrows) without necrosis. C-H are representative findings from granuloma-myositis patients who matched ENMC criteria for sIBM. H\&E frozen sections show muscle fibers atrophy (C, $D)$, endomysial inflammatory infiltrate surrounding non-necrotic muscle fibers (C), and rimmed vacuoles ( $D$, arrowheads). Upregulation of major histocompatibility complex I is noted in all muscle fibers (E). Cytochrome oxidase-negative muscle fibers are noted ( $F$, asterisks). Sarcoplasmic expression of TDP-43 (G) and p62 proteins $(\mathrm{H})$ is noted.

diagnosis of myositis, suggesting a slow progression of the disease. In addition, most of these patients (60\%) experienced dysphagia. All of these findings were in contrast to the findings recorded in granuloma-myositis patients without ENMC criteria for sIBM while being similar to the findings recorded in the sIBM control group. Moreover, in this group matching ENMC criteria, anti-cN1A antibodies were found in more than one third of the tested patients, while the 19 other autoantibodies associated with myositis tested negative. Finally, when performed, MRI of the lower limbs revealed muscle lesions (including edema, atrophy, and fatty infiltration) that were most commonly found in the quadriceps
$(3 / 5,60 \%$, prevailing involvement of vastus lateralis and medialis with relative sparing of the rectus femoris: $2 / 3$ ) and the gastrocnemius muscles $(3 / 5,60 \%)$ of granuloma-myositis patients matching ENMC criteria for sIBM (figure 3 ). This distribution matched the distribution reported in SIBM. ${ }^{16,17}$ Altogether, these features strongly support the diagnosis of sIBM in granuloma-myositis patients matching ENMC criteria for this disease.

However, all granuloma-myositis patients matching ENMC criteria for sIBM also had extramuscular involvements that were compatible with systemic granulomatosis including interstitial pneumonia $(n=4,40 \%)$, nodes $(n=4,40 \%)$, arthralgia $(n=3,30 \%)$, interstitial nephritis $(n=1,10 \%)$, and anterior uveitis $(\mathrm{n}=1,10 \%)$. Importantly, aside from arthralgia in 1 patient, these manifestations were not present in the sIBM control group. This indicates that these granulomamyositis patients had sIBM associated with sarcoidosis.

All of the granuloma-myositis patients matching ENMC criteria for sIBM were treated with corticosteroids $(n=10)$, methotrexate $(n=10)$, IV immunoglobulins $(n=4)$, antitumor necrosis factor drug $(\mathrm{n}=3)$, mycophenolate mofetil $(\mathrm{n}=2)$, hydroxychloroquine $(\mathrm{n}=2)$, or cyclophosphamide $(n=1)$ due to suspicion of muscle sarcoidosis. Despite a higher number of immunomodulatory drugs compared to both the control-myositis group $(2.2 \pm 0.4$ vs $1.3 \pm 0.2$, $p=0.08)$ and the remainder of the granuloma-myositis group (table $1, p=0.2$ ), only 1 granuloma-myositis patient matching ENMC criteria for sIBM attained muscle improvement (albeit without normalization of muscle strength and serum $\mathrm{CK}$ activity). This nonresponse to myopathy treatment was in contrast with the granuloma-myositis patients who did not match ENMC criteria for sIBM, but conversely similar to the control sIBM patients who received immunomodulatory treatment before sIBM diagnosis $(p<0.0001)$.

To test whether these results were maintained when applying other sets of diagnostic criteria for SIBM, the criteria proposed by Lloyd et al. ${ }^{14}$ were also used. As shown in table 2, agreement between Lloyd et al. ${ }^{14}$ and ENMC criteria was excellent in granuloma-myositis patients $(\kappa=0.82 \pm 0.12)$. Both the Lloyd et al. ${ }^{14}$ and ENMC criteria yielded the same rate of sIBM in granuloma-myositis patients, with the Lloyd et al. ${ }^{14}$ criteria further confirming the above results.

\section{Other granuloma-myositis patients generally did not match criteria for a well-defined myositis and responded to treatment}

Aside from 1 granuloma-myositis patient with myositis overlapping with systemic sclerosis (skin thickening proximal to the metacarpophalangeal joints and anti-Ku antibodies), ${ }^{18}$ the remaining $57 \%$ of granuloma-myositis patients who did not match the criteria for sIBM also did not match the criteria for any other well-defined myositis subtype, thereby suggesting pure sarcoidosis. One patient had anti-AMA2 without evidence of primary biliary cirrhosis, while the other 
Table 1 Characteristics of patients with granuloma-myositis using European Neuromuscular Centre (ENMC) criteria for sporadic inclusion body myositis (sIBM)

\begin{tabular}{|c|c|c|c|c|}
\hline & $\begin{array}{l}\text { With ENMC criteria } \\
\text { for } \operatorname{sIBM}(n=10)\end{array}$ & $\begin{array}{l}\text { Without ENMC criteria } \\
\text { for } \operatorname{sIBM}(n=13)\end{array}$ & $\begin{array}{l}\text { Control sIBM } \\
\text { group }(n=20)\end{array}$ & $p^{a}$ \\
\hline Sex ratio (F/M) & $0.7(4 / 6)$ & $0.9(6 / 7)$ & $0.7(8 / 12)$ & 0.9 \\
\hline Age at myositis diagnosis, y & $58(45-72)$ & $65(28-81)$ & $62(46-82)$ & 0.7 \\
\hline Follow-up, mo & $57(2-457)$ & $34(2-118)$ & $44(22-65)$ & 0.2 \\
\hline \multicolumn{5}{|l|}{ Muscle features } \\
\hline Time from weakness onset to diagnosis, mo & $31(12-240)$ & $10(2-108)$ & $30(4-64)$ & 0.04 \\
\hline Deep finger flexor weakness (recorded/assessed, \%) & $8 / 10(80)$ & $3 \mathrm{c} / 13(23)$ & $13 / 16(82)$ & 0.002 \\
\hline Myalgia, n (\%) & $5(50)$ & $6(46)$ & $7(35)$ & 0.7 \\
\hline Amyotrophy, n (\%) & $6(60)$ & $4(31)$ & $12(60)$ & 0.5 \\
\hline Dysphagia, n (\%) & $6(60)$ & $1(8)$ & $8(40)$ & 0.02 \\
\hline Axial weakness, n (\%) & $2(20)$ & $3(23)$ & $2(10)$ & 0.6 \\
\hline CK, U/L & $312(90-1,170)$ & $321(52-2,500)$ & $380(75-3,920)$ & 0.9 \\
\hline Muscle biopsy, n (\%) & $10(100)$ & $13(100)$ & $20(100)$ & \\
\hline Endomysial inflammatory infiltration & $9(90)$ & $8(62)$ & $19(95)$ & 0.03 \\
\hline Fiber atrophy & $7(70)$ & $5(38)$ & $18(90)$ & 0.007 \\
\hline Fiber necrosis & $3(30)$ & $4(31)$ & $10(50)$ & 0.6 \\
\hline Rimmed vacuoles & $4(40)$ & 0 & $12(60)$ & 0.002 \\
\hline Upregulation of MHC class I (recorded/assessed, \%) & $6 / 10(60)$ & $5 / 13(38)$ & $10 / 15(67)$ & 0.3 \\
\hline cOX -negative fibers (recorded/assessed, \%) & $4 / 10(40)$ & $1 / 9(11)$ & $7 / 20(35)$ & 0.3 \\
\hline $\begin{array}{l}\text { Protein accumulation (TDP } 43 \text { and/orP62) or 15- to 18-nm } \\
\text { tubulofilaments (recorded/assessed, \%) }\end{array}$ & $5 / 8(63)$ & $1 / 5(20)$ & $7 / 11(64)$ & 0.2 \\
\hline \multicolumn{5}{|l|}{ Myositis autoantibodies (specific or associated), $n(\%)^{\mathbf{b}}$} \\
\hline Anti-cN1A (recorded/assessed, \%) & $3 / 8(38)$ & $0 / 8$ & NA & - \\
\hline Anti-Ku & $0 / 9$ & $1 / 12(8)$ & $0 / 15$ & - \\
\hline Antimitochondrial antibodies & $0 / 9$ & $1 / 12(8)$ & $0 / 12$ & - \\
\hline Other 17 myositis-specific or associated autoantibodies ${ }^{b}$ & $0 / 9$ & $0 / 12$ & $0 / 15$ & - \\
\hline \multicolumn{5}{|l|}{ Extramuscular features, $\mathrm{n}(\%)$} \\
\hline $\begin{array}{l}\text { Features found in granulomatous myositis, but not in } \\
\text { classical cases of sIBM }\end{array}$ & $10(100)$ & $11(85)$ & $1(5)$ & $<0.0001$ \\
\hline Clinical signs & $10(100)$ & $11(85)$ & $1(5)$ & $<0.0001$ \\
\hline Arthralgia & $3(30)$ & $5(38)$ & $1(5)$ & 0.06 \\
\hline Interstitial pneumonia & $4(40)$ & $7(54)$ & 0 & 0.001 \\
\hline Nodes & $4(40)$ & $5(38)$ & 0 & 0.007 \\
\hline Cutaneous granulomatosis/erythema nodosum & 0 & $4(31)$ & 0 & - \\
\hline Granulomatous hepatitis & 0 & $2(15)$ & 0 & - \\
\hline Interstitial nephritis & $1(10)$ & $1(8)$ & 0 & - \\
\hline Anterior uveitis & $1(10)$ & 0 & 0 & - \\
\hline
\end{tabular}


Table 1 Characteristics of patients with granuloma-myositis using European Neuromuscular Centre (ENMC) criteria for sporadic inclusion body myositis (sIBM) (continued)

\begin{tabular}{|c|c|c|c|c|}
\hline & $\begin{array}{l}\text { With ENMC criteria } \\
\text { for } \operatorname{sIBM}(n=10)\end{array}$ & $\begin{array}{l}\text { Without ENMC criteria } \\
\text { for } \operatorname{sIBM}(n=13)\end{array}$ & $\begin{array}{l}\text { Control sIBM } \\
\text { group }(n=20)\end{array}$ & $p^{a}$ \\
\hline Biological signs & $5(50)$ & $7(54)$ & 0 & 0.0007 \\
\hline Hypercalcemia & $3 / 10(30)$ & $2 / 12(17)$ & 0 & 0.04 \\
\hline Increased ACE & $2 / 8(25)$ & $6 / 10(60)$ & 0 & 0.0007 \\
\hline Cancer & $1(10)$ & 0 & $2(10)$ & - \\
\hline \multicolumn{5}{|l|}{ Treatment } \\
\hline No. of immunomodulators & $2.2( \pm 0.4)$ & $1.4( \pm 0.3)$ & $2.0( \pm 0.8)$ & 0.3 \\
\hline Response to treatment, $\mathrm{n}(\%)$ & $1(10)$ & $10(77)$ & $1 / 6^{d}(16)$ & $<0.002$ \\
\hline
\end{tabular}

Abbreviations: $\mathrm{ACE}=$ angiotensin-converting enzyme blood level; $\mathrm{CK}=$ creatine kinase blood activity; $\mathrm{COX}=$ cytochrome c oxidase histochemical staining; $\mathrm{MHC}$ $=$ major histocompatibility complex; NA = not available.

a Difference among the 3 groups using $\chi^{2}$ test for categorical variables and Kruskal-Wallis test for quantitative variables.

${ }^{\mathrm{b}}$ Anti-Jo1 and anti-U1 RNP was assessed in all patients. All the additional following myositis-associated autoantibodies were assessed in 21 patients: anti-PL7, anti-PL12, anti-EJ, anti-OJ, anti-KS, anti-Zo, anti-Ha, anti-Mi2, anti-MDA5, anti-NXP2, anti-Tif-1y, anti-SAE, anti-Ku, anti-PM/SCl, anti-SRP, anti-HMGCR.

${ }^{c}$ COX, TDP43, and P62 staining were available in these 3 patients. A patient did not match ENMC criteria for sIBM because of age at symptom onset before 45 years (40 years) although he had several of the other ENMC features of sIBM (notably weakness prevailing on knee extension and finger flexion, endomysia infiltrate invading nonnecrotic muscle fibers, COX-negative fibers, positive staining for P62 and TDP43; no rimmed vacuole was found). The patient matched the Lloyd et al. ${ }^{14}$ criteria for sIBM (see also table 2). The 2 other patients had less-pronounced finger flexion weakness than shoulder abduction weakness and they did not match the Lloyd et al. ${ }^{14}$ criteria.

${ }^{d}$ Six patients were treated with immunomodulators before sIBM diagnosis.

autoantibodies associated with well-defined myositis tested negative in available serum from this group. As shown in table 1 , as compared with patients matching the ENMC criteria for sIBM, these patients more frequently had specific signs of granulomatosis, especially sarcoid-like skin lesions ( $31 \%$ vs 0$)$. Granulomas were more often found in more than 1 organ in this group (61\% vs $20 \%)$. These patients received corticosteroids $(\mathrm{n}=12)$, methotrexate $(\mathrm{n}=9)$, mycophenolate mofetil $(\mathrm{n}=2)$, azathioprine $(\mathrm{n}=2)$, hydroxychloroquine ( $\mathrm{n}$ $=2)$, or cyclophosphamide $(n=1)$. The proportion of patients who reached the definition of muscle improvement at last follow-up in this group did not differ from the patients in the control-myositis group ( $77 \%$ vs $70 \%, p=1.0$ ).

The above results remained unchanged when the Lloyd et al. ${ }^{14}$ criteria were applied for the diagnosis of sIBM (table 2).

\section{Matching criteria for sIBM independently predicts a poor muscle response in granuloma- myositis patients}

In the overall granuloma-myositis population, approximately half of the patients had muscle response to treatment vs $70 \%$

Figure 3 Representative MRI findings in the lower limbs from a granuloma-myositis patient who matched European Neuromuscular Centre criteria for sporadic inclusion body myositis
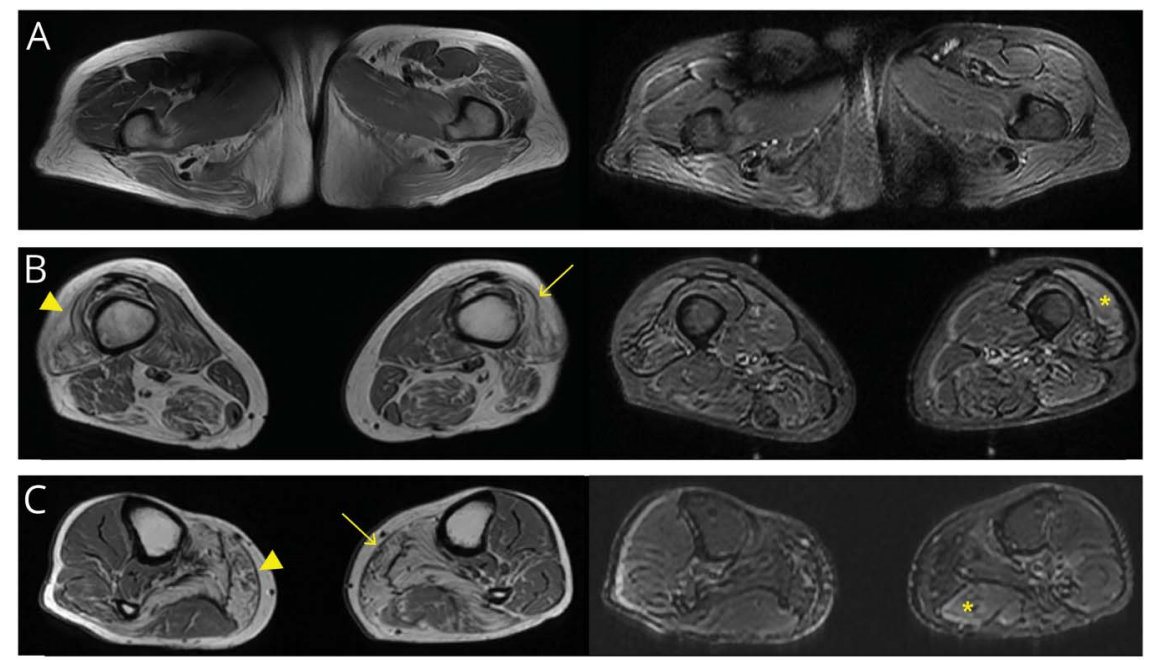

T1-weighted (left panels) and short tau inversion recovery sequences (right panels) are shown. (A) No muscle lesion is shown in the pelvis. (B) Atrophy (arrowhead), fatty infiltration (arrow), and edema (asterisk) of the distal part of the vastus lateralis, with relative sparing of the posterior part of the upper legs. (C) Atrophy (arrowhead), fatty infiltration (arrow), and edema (asterisk) of the muscles of the posterior part of the lower legs with relative sparing of the anterolateral part of the lower legs. The medial parts of the gastrocnemius muscles are severely affected. 
Table 2 Characteristics of patients with granuloma-myositis using the Lloyd et al. ${ }^{14}$ criteria for sporadic inclusion body myositis (sIBM)

\begin{tabular}{|c|c|c|c|c|}
\hline & $\begin{array}{l}\text { With Lloyd et al. }{ }^{14} \\
\text { criteria for sIBM }(n=10)\end{array}$ & $\begin{array}{l}\text { Without Lloyd et al. }{ }^{14} \\
\text { criteria for sIBM }(n=13)\end{array}$ & $\begin{array}{l}\text { Control sIBM } \\
\text { group }(n=20)\end{array}$ & $p^{a}$ \\
\hline Sex ratio (F/M) & $0.4(3 / 7)$ & $1.2(7 / 6)$ & $0.7(8 / 12)$ & 0.8 \\
\hline Age at myositis diagnosis, y & $56(40-72)$ & $65(28-81)$ & $62(46-82)$ & 0.7 \\
\hline Follow-up, mo & $55(2-457)$ & $34(2-118)$ & $44(22-65)$ & 0.3 \\
\hline \multicolumn{5}{|l|}{ Muscle features } \\
\hline Time from weakness onset to diagnosis, mo & $24(4-240)$ & $11(2-108)$ & $30(4-64)$ & 0.06 \\
\hline Deep finger flexor weakness (recorded/assessed, \%) & $8 / 10(80)$ & $3 / 13(23)$ & $13 / 16(82)$ & 0.002 \\
\hline Myalgia, n (\%) & $6(60)$ & $5(38)$ & $7(35)$ & 0.4 \\
\hline Amyotrophy, n (\%) & $6(60)$ & $4(31)$ & $12(60)$ & 0.5 \\
\hline Dysphagia (recorded/assessed, \%) & $6(60)$ & $1(8)$ & $8(40)$ & 0.02 \\
\hline Axial weakness, n (\%) & $2(20)$ & $3(23)$ & $2(10)$ & 0.6 \\
\hline CK, U/L & $342(90-1,170)$ & $217(52-2,500)$ & $380(75-3,920)$ & 0.9 \\
\hline Muscle biopsy, n (\%) & $10(100)$ & $13(100)$ & $20(100)$ & \\
\hline Endomysial inflammatory infiltration & $10(100)$ & $7(54)$ & $19(95)$ & 0.02 \\
\hline Fiber atrophy & $8(80)$ & $4(31)$ & $18(90)$ & 0.001 \\
\hline Fiber necrosis & $4(40)$ & $3(23)$ & $10(50)$ & 0.3 \\
\hline Rimmed vacuoles & $4(40)$ & 0 & $12(60)$ & 0.002 \\
\hline Upregulation of MHC class I & $7 / 10(70)$ & $4 / 13(31)$ & $10 / 15(67)$ & 0.09 \\
\hline COX-negative fibers (recorded/assessed, \%) & $5 / 10(50)$ & $0 / 9$ & $7 / 20(35)$ & 0.02 \\
\hline $\begin{array}{l}\text { Protein accumulation (TDP } 43 \text { or P62) or 15- to 18-nm } \\
\text { tubulofilaments (recorded/assessed, \%) }\end{array}$ & $6 / 8(75)$ & $0 / 5$ & $7 / 11(64)$ & 0.2 \\
\hline \multicolumn{5}{|l|}{ Myositis autoantibodies (specific or associated), $n(\%)^{\mathbf{b}}$} \\
\hline Anti-cN1A (recorded/assessed, \%) & $3 / 7(43)$ & $0 / 9$ & NA & - \\
\hline Anti-Ku & 0 & $1 / 12(8)$ & $0 / 15$ & - \\
\hline Antimitochondrial antibodies & 0 & $1 / 12(8)$ & $0 / 12$ & - \\
\hline $\begin{array}{l}\text { Other } 17 \text { myositis-specific or associated } \\
\text { autoantibodies }^{\mathbf{b}}\end{array}$ & $0 / 9$ & $0 / 12$ & $0 / 15$ & - \\
\hline \multicolumn{5}{|l|}{ Extramuscular features, $n(\%)$} \\
\hline $\begin{array}{l}\text { Features found in granulomatous myositis, but not in } \\
\text { classical cases of sIBM }\end{array}$ & $10(100)$ & $11(85)$ & $1(5)$ & $<0.0001$ \\
\hline Clinical signs & $10(100)$ & $11(85)$ & $1(5)$ & $<0.0001$ \\
\hline Arthralgia & $3(30)$ & $5(38)$ & $1(5)$ & 0.06 \\
\hline Interstitial pneumonia & $5(50)$ & $6(46)$ & 0 & 0.001 \\
\hline Nodes & $4(40)$ & $5(38)$ & 0 & 0.007 \\
\hline Cutaneous granulomatosis/erythema nodosum & $1(10)$ & $3(23)$ & 0 & - \\
\hline Granulomatous hepatitis & $1(10)$ & $1(8)$ & 0 & - \\
\hline Interstitial nephritis & 0 & $2(15)$ & 0 & - \\
\hline Anterior uveitis & $1(10)$ & 0 & 0 & - \\
\hline
\end{tabular}


Table 2 Characteristics of patients with granuloma-myositis using the Lloyd et al. ${ }^{14}$ criteria for sporadic inclusion body myositis (sIBM) (continued)

\begin{tabular}{|c|c|c|c|c|}
\hline & $\begin{array}{l}\text { With Lloyd et al. }{ }^{14} \\
\text { criteria for sIBM }(n=10)\end{array}$ & $\begin{array}{l}\text { Without Lloyd et al. }{ }^{14} \\
\text { criteria for sIBM }(n=13)\end{array}$ & $\begin{array}{l}\text { Control sIBM } \\
\text { group }(n=20)\end{array}$ & $p^{a}$ \\
\hline Biological signs & $5(50)$ & $7(54)$ & 0 & 0.0007 \\
\hline Hypercalcemia & $3 / 10(30)$ & 2/12 (17) & 0 & 0.04 \\
\hline Increased ACE & $2 / 8(25)$ & $6 / 10(60)$ & 0 & 0.0007 \\
\hline Cancer & $1(10)$ & 0 & $2(10)$ & - \\
\hline \multicolumn{5}{|l|}{ Treatment } \\
\hline No. of immunomodulators & $2.1( \pm 0.4)$ & $1.4( \pm 0.3)$ & $2.0( \pm 0.8)$ & 0.4 \\
\hline Response to treatment, $\mathrm{n}(\%)$ & $1(10)$ & $10(77)$ & $1 / 6^{c}(16)$ & $<0.002$ \\
\hline \multicolumn{5}{|c|}{$\begin{array}{l}\text { Abbreviations: ACE = angiotensin-converting enzyme blood level; CK = creatine kinase blood activity; COX= cytochrome coxidase histochemical staining; MHC } \\
=\text { major histocompatibility complex; NA = not available. } \\
\text { All the following additional myositis-associated autoantibodies were assessed in } 21 \text { patients: anti-PL7, anti-PL12, anti-EJ, anti-OJ, anti-KS, anti-Zo, anti-Ha, anti- } \\
\text { Mi2, anti-MDA5, anti-NXP2, anti-Tif-1y, anti-SAE, anti-Ku, anti-PM/Scl, anti-SRP, anti-HMGCR. } \\
\text { a Difference among the } 3 \text { groups using } \chi^{2} \text { test for categorical variables and Kruskal-Wallis test for quantitative variables. } \\
\text { b Anti-Jo1 and anti-U1 RNP antibodies were assessed in all patients. } \\
\text { ' Six patients were treated with immunomodulators before slBM diagnosis. }\end{array}$} \\
\hline
\end{tabular}

of the control-myositis patients $(p=0.1)$. As shown in table 3 , nonresponder granuloma-myositis patients featured a longer delay from symptoms to diagnosis (27 vs $12, p=0.08$ ) and more frequently matched ENMC criteria for sIBM $(75 \%$ vs $9 \%, p=0.003$ ), had COX-negative fibers ( $42 \%$ vs $0, p=0.1$ ), and had anti-cN1A autoantibodies ( $38 \%$ vs $0, p=0.2$ ). In multivariate analysis, matching ENMC criteria for SIBM was the sole feature independently associated with nonmuscular response to treatment $(p<0.001)$. The same result was obtained when the Lloyd et al. ${ }^{14}$ criteria were applied.

\section{Discussion}

Response to sarcoidosis myopathy treatment has been reported to be variable and unpredictable. ${ }^{8}$ Although there are no universally accepted criteria for sarcoidosis, all of our patients matched the criteria proposed by Valeyre et al. ${ }^{4}$ Indeed, all had signs compatible with this disease, together with histopathologic demonstration of noncaseating granuloma in at least 1 organ and no alternative disease known to cause granuloma. Our data, based on the largest series of patients with myopathy and granulomatosis, demonstrated that these patients encompass a heterogeneous group of inflammatory muscle diseases whose identification predicts whether they respond to treatment or not: fulfilling the sIBM criteria was the sole factor associated with the absence of muscle improvement in granuloma-myositis patients.

Most importantly, our data demonstrate that granulomamyositis patients frequently had sIBM. About half of our granuloma-myositis patients met the criteria for this disease, whether using the ENMC or Lloyd et al. ${ }^{14}$ criteria, the 2 bestperforming criteria reported to date. ${ }^{12}$ Moreover, aside from granuloma, clinical, pathologic, serologic, and MRI characteristics of the myopathy as well as its nonresponse to treatment were similar to those in patients with sIBM without granuloma. Moreover, the proportion of granuloma-myositis patients matching the criteria for sIBM who tested positive for anti-cN1A antibodies was similar to that previously reported in a sIBM population. ${ }^{19}$ In addition, the distribution of MRI muscle lesions found in these granuloma-myositis patients matched the pattern of muscle involvement reported in sIBM. ${ }^{16,17}$

sIBM is frequently associated (up to $33 \%$ ) with other immune-driven diseases ${ }^{20}$ and has been described in conjunction with sarcoidosis in case reports. ${ }^{9,10}$ Extramuscular symptoms including joint, lung, nodes, ocular, and kidneys were observed in all our granuloma-myositis patients matching sIBM criteria. Such extramuscular involvements were not recorded in SIBM without granuloma but are nonetheless frequent in sarcoidosis. This indicates that these granulomamyositis patients had sIBM associated with sarcoidosis. The pathomechanisms that link sIBM and granuloma were not revealed by our study.

Aside from the above granuloma-myositis patients meeting the sIBM criteria, the other half of our patients presented a form of myositis that could not be classified in a well-defined myositis group aside from exhibiting sarcoidosis. Moreover, the majority of these patients had extramuscular signs suggestive of sarcoidosis and uncommon for other myositis types. These features suggest that these patients likely had pure muscle sarcoidosis. The proportion of response to myopathy treatment in this group did not differ from that of the controlmyositis group.

Antimitochondrial antibodies have been variably associated with muscle granuloma ( $0 \%-25 \%)$ and cardiac involvement $(30 \%-40 \%)$ in patients with myositis. ${ }^{21,22}$ In the present 
Table 3 Predictive factors of muscular response in patients with granuloma-myositis

\begin{tabular}{|c|c|c|c|c|c|}
\hline & $\begin{array}{l}\text { Responders } \\
(n=11)\end{array}$ & $\begin{array}{l}\text { Nonresponders } \\
(n=12)\end{array}$ & $\begin{array}{l}\text { Univariate } \\
\text { analysis, } p^{\mathrm{a}}\end{array}$ & $\begin{array}{l}\text { Multivariate } \\
\text { analysis } 1, p^{b}\end{array}$ & $\begin{array}{l}\text { Multivariate } \\
\text { analysis } 2, p^{6}\end{array}$ \\
\hline $\operatorname{Sex}(F / M)$ & $6 / 5$ & $4 / 8$ & 0.5 & - & - \\
\hline Age at myositis diagnosis, y & $65(44-77)$ & $58(28-81)$ & 0.8 & - & - \\
\hline Time from weakness onset to diagnosis, mo & $12(2-108)$ & $27(4-240)$ & 0.08 & - & - \\
\hline sIBM according to ENMC criteria, $n(\%)^{c}$ & $1(9)$ & $9(75)$ & 0.003 & $<0.001$ & - \\
\hline slBM according to Lloyd et al. ${ }^{14}$ criteria, $n(\%)^{c}$ & $1(9)$ & $9(75)$ & 0.003 & - & $<0.001$ \\
\hline Amyotrophy, n (\%) & $4(36)$ & $6(50)$ & 0.7 & - & - \\
\hline Deep finger flexor weakness (recorded/assessed, \%) & $3 / 11(27)$ & $8 / 12(66)$ & 0.09 & - & - \\
\hline Distal weakness, n (\%) & $6(55)$ & $11(92)$ & 0.07 & - & - \\
\hline Dysphagia, n (\%) & $2(18)$ & $5(42)$ & 0.4 & - & - \\
\hline CK, U/L & $\begin{array}{l}350 \\
(67-2,500)\end{array}$ & $279(52-1,070)$ & 0.6 & - & - \\
\hline Myositis-specific autoantibodies, n (\%) & $1 / 10(10)$ & $0 / 11$ & 0.5 & 0.5 & 0.6 \\
\hline Anti-cN1A antibodies (recorded/assessed, \%) & $0 / 8$ & $3 / 8(38)$ & 0.2 & - & - \\
\hline Muscle biopsy, n (\%) & $11(100)$ & $12(100)$ & & & \\
\hline Endomysial inflammation & $7(64)$ & $10(83)$ & 0.3 & - & - \\
\hline Fiber atrophy & $5(55)$ & $7(58)$ & 0.4 & - & - \\
\hline Fiber necrosis & $3(27)$ & $4(33)$ & 0.1 & - & - \\
\hline coX-negative fibers (recorded/assessed, \%) & $0 / 7$ & $5 / 12(42)$ & 0.1 & - & - \\
\hline $\begin{array}{l}\text { Protein accumulation (TDP } 43 \text { or P62) or } 15 \text { - to 18-nm } \\
\text { tubulofilaments (recorded/assessed, \%) }\end{array}$ & $1 / 5(20)$ & $5 / 8(63)$ & 0.3 & - & - \\
\hline Arthralgia, n (\%) & $4(36)$ & $4(33)$ & 1.0 & - & - \\
\hline Interstitial lung disease, $\mathbf{n}(\%)$ & $6(55)$ & $4(33)$ & 0.4 & - & - \\
\hline $\begin{array}{l}\text { Granulomatous-specific extramuscular features, } \\
n(\%)^{d}\end{array}$ & $2(18)$ & $5(42)$ & 0.4 & 0.2 & 0.1 \\
\hline Hypercalcemia, n (\%) & $1(9)$ & $4(33)$ & 0.3 & - & - \\
\hline Increased ACE, n (\%) & $4(36)$ & $4(33)$ & 1.0 & - & - \\
\hline
\end{tabular}

Abbreviations: $\mathrm{ACE}=$ angiotensin-converting enzyme; $\mathrm{CK}=$ creatine kinase blood level; $\mathrm{COX}=$ cytochrome $\mathrm{c}$ oxidase histochemical staining; $\mathrm{ENMC}=$ European Neuromuscular Centre; SIBM = sporadic inclusion body myositis.

${ }^{a}$ Difference between responder and nonresponder groups using Fisher exact test for categorical variables and Mann-Whitney test for quantitative variables.

${ }^{\mathrm{b}}$ Using multiple logistic regression.

CLloyd et al. ${ }^{4}$ criteria and ENMC criteria were discordant for the diagnosis of sIBM in only 2 granuloma-myositis patients. (1) One patient who did not match ENMC criteria for SIBM due to age at symptoms onset before 45 years ( 40 years) despite other ENMC features of sIBM (weakness prevailing on knee extension and finger flexion, endomysial infiltrate invading nonnecrotic muscle fibers, COX-negative fibers, positive staining for P62 and TDP43, no rimmed vacuole) matched Lloyd et al. ${ }^{14}$ criteria for sIBM. This patient did not respond to treatment. (2) Another patient with weakness prevailing on knee extension and finger flexion, with upregulation of major histocompatibility complex class I but no endomysial inflammation, rimmed vacuole, COX-negative fibers, or P62 or TDP43, met ENMC criteria for probable sIBM but did not match Lloyd et al. ${ }^{14}$ criteria. This patient also did not respond to treatment.

${ }^{d}$ Granulomatous-specific extramuscular features included cutaneous granulomatosis, erythema nodosum, interstitial nephritis, anterior uveitis, and choroidal granuloma.

cohort, anti-AMA2 was positive in 1 out of 20 granulomamyositis patients $(5 \%)$. This patient did not match the criteria for a well-defined myositis and had no cardiac involvement. None of the 19 control-myositis patients had anti-AMA2 $(p=0.5)$.

Early diagnosis and treatment of symptomatic sarcoidosis improves the prognosis of these life-threatening conditions. ${ }^{23}$ Conversely, immunomodulating agents are not effective and may exacerbate the risk of progression of disability in patients with sIBM. ${ }^{24}$ In conjunction with the above, the present data indicate that granuloma-myositis patients should be carefully screened for sIBM associated with sarcoidosis in order to best tailor their care.

\section{Acknowledgment}

The authors thank the practitioners for enrolling patients; the MyositEst network, the Club Rhumatisme et Inflammation national network, and the French myositis network for 
spreading electronic letters; and Pierre Pothier for proofreading the manuscript.

\section{Study funding}

No targeted funding reported.

\section{Disclosure}

The authors report no disclosures relevant to the manuscript. Go to Neurology.org/N for full disclosures.

\section{Publication history}

Received by Neurology November 8, 2018. Accepted in final form August 30, 2019.

Appendix Authors

\begin{tabular}{llll}
\hline Name & Location & Role & Contribution \\
\hline $\begin{array}{l}\text { Yannick } \\
\text { Dieudonné, }\end{array}$ & Hôpitaux & Aniversitaires de & Acquisition, analysis, \\
MD & Strasbourg, & & $\begin{array}{l}\text { and interpretation of } \\
\text { the data, drafted the } \\
\text { France }\end{array}$ \\
& & $\begin{array}{l}\text { manuscript for } \\
\text { intellectual content, } \\
\text { statistical analysis. }\end{array}$
\end{tabular}

\begin{tabular}{|c|c|c|c|}
\hline $\begin{array}{l}\text { Yves } \\
\text { Allembach, } \\
\text { MD, PhD }\end{array}$ & $\begin{array}{l}\text { Hôpital } \\
\text { Universitaire } \\
\text { Pitié-Salpêtrière, } \\
\text { Paris, France }\end{array}$ & Author & $\begin{array}{l}\text { Acquisition and analysis } \\
\text { of the data, revised the } \\
\text { manuscript for } \\
\text { intellectual content. }\end{array}$ \\
\hline $\begin{array}{l}\text { Olivier } \\
\text { Benveniste, } \\
\text { MD, PhD }\end{array}$ & $\begin{array}{l}\text { Hôpital } \\
\text { Universitaire } \\
\text { Pitié-Salpêtrière, } \\
\text { Paris, France }\end{array}$ & Author & $\begin{array}{l}\text { Acquisition and analysis } \\
\text { of the data, revised the } \\
\text { manuscript for } \\
\text { intellectual content. }\end{array}$ \\
\hline $\begin{array}{l}\text { Sarah } \\
\text { Leonard- } \\
\text { Louis, MD }\end{array}$ & $\begin{array}{l}\text { Hôpital } \\
\text { Universitaire } \\
\text { Pitié-Salpêtrière, } \\
\text { Paris, France }\end{array}$ & Author & $\begin{array}{l}\text { Acquisition and analysis } \\
\text { of the data, revised the } \\
\text { manuscript for } \\
\text { intellectual content. }\end{array}$ \\
\hline $\begin{array}{l}\text { Baptiste } \\
\text { Hervier, MD, } \\
\text { PhD }\end{array}$ & $\begin{array}{l}\text { Hôpital } \\
\text { Universitaire } \\
\text { Pitié-Salpêtrière, } \\
\text { Paris, France }\end{array}$ & Author & $\begin{array}{l}\text { Acquisition and analysis } \\
\text { of the data, revised the } \\
\text { manuscript for } \\
\text { intellectual content. }\end{array}$ \\
\hline $\begin{array}{l}\text { Kuberaka } \\
\text { Mariampillai, } \\
\text { PhD }\end{array}$ & $\begin{array}{l}\text { Hôpital } \\
\text { Universitaire } \\
\text { Pitié-Salpêtrière, } \\
\text { Paris, France }\end{array}$ & Author & $\begin{array}{l}\text { Acquisition and analysis } \\
\text { of the data, revised the } \\
\text { manuscript for } \\
\text { intellectual content. }\end{array}$ \\
\hline $\begin{array}{l}\text { Benoit } \\
\text { Nespola, } \\
\text { PharmD }\end{array}$ & $\begin{array}{l}\text { Hôpitaux } \\
\text { Universitaires de } \\
\text { Strasbourg, } \\
\text { France }\end{array}$ & Author & $\begin{array}{l}\text { Acquisition and analysis } \\
\text { of the data, revised the } \\
\text { manuscript for } \\
\text { intellectual content. }\end{array}$ \\
\hline $\begin{array}{l}\text { Béatrice } \\
\text { Lannes, MD, } \\
\text { PhD }\end{array}$ & $\begin{array}{l}\text { Hôpitaux } \\
\text { Universitaires de } \\
\text { Strasbourg, } \\
\text { France }\end{array}$ & Author & $\begin{array}{l}\text { Acquisition and analysis } \\
\text { of the data, revised the } \\
\text { manuscript for } \\
\text { intellectual content. }\end{array}$ \\
\hline $\begin{array}{l}\text { Andoni } \\
\text { Echaniz- } \\
\text { Laguna, MD, } \\
\text { PhD }\end{array}$ & $\begin{array}{l}\text { Hôpitaux } \\
\text { Universitaires de } \\
\text { Strasbourg, } \\
\text { France }\end{array}$ & Author & $\begin{array}{l}\text { Acquisition and analysis } \\
\text { of the data, revised the } \\
\text { manuscript for } \\
\text { intellectual content. }\end{array}$ \\
\hline $\begin{array}{l}\text { Daniel } \\
\text { Wendling, MD, } \\
\text { PhD }\end{array}$ & $\begin{array}{l}\text { Hôpital } \\
\text { Universitaire de } \\
\text { Besançon, } \\
\text { France }\end{array}$ & Author & $\begin{array}{l}\text { Acquisition and analysis } \\
\text { of the data, revised the } \\
\text { manuscript for } \\
\text { intellectual content. }\end{array}$ \\
\hline $\begin{array}{l}\text { Christian Von } \\
\text { Frenckel, MD, } \\
\text { PhD }\end{array}$ & $\begin{array}{l}\text { Hôpital } \\
\text { Universitaire } \\
\text { Sart-Tilman, } \\
\text { Liège, Belgique }\end{array}$ & Author & $\begin{array}{l}\text { Acquisition and analysis } \\
\text { of the data, revised the } \\
\text { manuscript for } \\
\text { intellectual content. }\end{array}$ \\
\hline
\end{tabular}

Appendix (continued)

\begin{tabular}{|c|c|c|c|}
\hline Name & Location & Role & Contribution \\
\hline $\begin{array}{l}\text { Nicolas } \\
\text { Poursac, MD }\end{array}$ & $\begin{array}{l}\text { Hôpital } \\
\text { Universitaire de } \\
\text { Bordeaux, } \\
\text { France }\end{array}$ & Author & $\begin{array}{l}\text { Acquisition and analysis } \\
\text { of the data, revised the } \\
\text { manuscript for } \\
\text { intellectual content. }\end{array}$ \\
\hline $\begin{array}{l}\text { Emmanuel } \\
\text { Mortier, MD }\end{array}$ & $\begin{array}{l}\text { Hôpital } \\
\text { Universitaire } \\
\text { Louis Mourier, } \\
\text { Colombes, } \\
\text { France }\end{array}$ & Author & $\begin{array}{l}\text { Acquisition and analysis } \\
\text { of the data, revised the } \\
\text { manuscript for } \\
\text { intellectual content. }\end{array}$ \\
\hline $\begin{array}{l}\text { Christian } \\
\text { Lavigne, MD }\end{array}$ & $\begin{array}{l}\text { Hôpital } \\
\text { Universitaire } \\
\text { d'Angers, France }\end{array}$ & Author & $\begin{array}{l}\text { Acquisition and analysis } \\
\text { of the data, revised the } \\
\text { manuscript for } \\
\text { intellectual content. }\end{array}$ \\
\hline $\begin{array}{l}\text { Olivier } \\
\text { Hinschberger, } \\
\text { MD }\end{array}$ & $\begin{array}{l}\text { Hôpital Emile } \\
\text { Muller, } \\
\text { Mulhouse, } \\
\text { France }\end{array}$ & Author & $\begin{array}{l}\text { Acquisition and analysis } \\
\text { of the data, revised the } \\
\text { manuscript for } \\
\text { intellectual content. }\end{array}$ \\
\hline $\begin{array}{l}\text { Julie Magnant, } \\
\text { MD }\end{array}$ & $\begin{array}{l}\text { Hôpital } \\
\text { Universitaire de } \\
\text { Tours, France }\end{array}$ & Author & $\begin{array}{l}\text { Acquisition and analysis } \\
\text { of the data, revised the } \\
\text { manuscript for } \\
\text { intellectual content. }\end{array}$ \\
\hline $\begin{array}{l}\text { Jacques-Eric } \\
\text { Gottengerg, } \\
\text { MD, PhD }\end{array}$ & $\begin{array}{l}\text { Hôpitaux } \\
\text { Universitaires de } \\
\text { Strasbourg, } \\
\text { France }\end{array}$ & Author & $\begin{array}{l}\text { Acquisition and analysis } \\
\text { of the data, revised the } \\
\text { manuscript for } \\
\text { intellectual content. }\end{array}$ \\
\hline $\begin{array}{l}\text { Bernard Geny, } \\
\text { MD, PhD }\end{array}$ & $\begin{array}{l}\text { Hôpitaux } \\
\text { Universitaires de } \\
\text { Strasbourg, } \\
\text { France }\end{array}$ & Author & $\begin{array}{l}\text { Acquisition and analysis } \\
\text { of the data, revised the } \\
\text { manuscript for } \\
\text { intellectual content. }\end{array}$ \\
\hline $\begin{array}{l}\text { Jean Sibilia, } \\
\text { MD, PhD }\end{array}$ & $\begin{array}{l}\text { Hôpitaux } \\
\text { Universitaires de } \\
\text { Strasbourg, } \\
\text { France }\end{array}$ & Author & $\begin{array}{l}\text { Acquisition and analysis } \\
\text { of the data, revised the } \\
\text { manuscript for } \\
\text { intellectual content. }\end{array}$ \\
\hline $\begin{array}{l}\text { Alain Meyer, } \\
\text { MD, PhD }\end{array}$ & $\begin{array}{l}\text { Hôpitaux } \\
\text { Universitaires de } \\
\text { Strasbourg, } \\
\text { France }\end{array}$ & Author & $\begin{array}{l}\text { Acquisition, analysis, } \\
\text { and interpretation of } \\
\text { the data, drafted the } \\
\text { manuscript for } \\
\text { intellectual content, } \\
\text { statistical analysis. }\end{array}$ \\
\hline
\end{tabular}

\section{References}

1. Senécal JL, Raynauld JP, Troyanov Y. Editorial: A new classification of adult autoimmune myositis. Arthritis Rheum 2017;69:878-884.

2. Selva-O'Callaghan A, Pinal-Fernandez I, Trallero-Araguás E, Milisenda JC, GrauJunyent JM, Mammen AL. Classification and management of adult inflammatory myopathies. Lancet Neurol 2018;17:816-828.

3. Meyer A, Lannes B, Goetz J, et al. Inflammatory muscle disease: a new landscape. Joint Bone Spine 2018;85:23-33.

4. Valeyre D, Prasse A, Nunes H, Uzunhan Y, Brillet PY, Müller-Quernheim J. Sarcoidosis. Lancet2014;383:1155-1167.

5. Marcellis RGJ, Lenssen AF, Elfferich MDP, et al. Exercise capacity, muscle strength and fatigue in sarcoidosis. Eur Respir J 2011;38:628-634.

6. Spruit MA, Thomeer MJ, Gosselink R, et al. Skeletal muscle weakness in patients with sarcoidosis and its relationship with exercise intolerance and reduced health status. Thorax 2005;60:32-38.

7. Fayad F, Lioté F, Berenbaum F, Orcel P, Bardin T. Muscle involvement in sarcoidosis: a retrospective and followup studies. J Rheumatol 2006;33:98-103.

8. Prieto-González S, Grau JM. Diagnosis and classification of granulomatous myositis. Autoimmun Rev 2014;13:372-374.

9. Sakai K, Ikeda Y, Ishida C, et al. Inclusion body myositis with granuloma formation in muscle tissue. Neuromuscul Disord 2015;25:706-712.

10. Lavian M, Goyal N, Mozaffar T. Sporadic inclusion body myositis misdiagnosed as idiopathic granulomatous myositis. Neuromuscul Disord 2016;26:741-743.

11. Asanuma Y, Koichihara R, Koyama S, et al. Antisynthetase syndrome associated with sarcoidosis. Intern Med 2006;45:1065-1068.

12. Lundberg IE, Tjärnlund A, Bottai M, et al. 2017 European League Against Rheumatism/American College of Rheumatology classification criteria for adult and 
juvenile idiopathic inflammatory myopathies and their major subgroups. Arthritis Rheum 2017;69:2271-2282.

13. Rose MR; ENMC IBM Working Group. 188th ENMC International Workshop: inclusion body myositis, 2-4 December 2011, Naarden, The Netherlands. Neuromuscul Disord 2013;23:1044-1055.

14. Lloyd TE, Mammen AL, Amato AA, Weiss MD, Needham M, Greenberg SA. Evaluation and construction of diagnostic criteria for inclusion body myositis. Neurology 2014;83:426-433.

15. Cox FM, Verschuuren JJ, Verbist BM, Niks EH, Wintzen AR, Badrising UA. Detecting dysphagia in inclusion body myositis. J Neurol 2009;256:2009-2013.

16. Cox FM, Reijnierse M, van Rijswijk CSP, Wintzen AR, Verschuuren JJ, Badrising UA. Magnetic resonance imaging of skeletal muscles in sporadic inclusion body myositis. Rheumatol Oxf Engl 2011;50:1153-1161.

17. Tasca G, Monforte M, De Fino C, Kley RA, Ricci E, Mirabella M. Magnetic resonance imaging pattern recognition in sporadic inclusion-body myositis. Muscle Nerve 2015; 52:956-962.

18. van den Hoogen F, Khanna D, Fransen J, et al. Classification criteria for systemic sclerosis: an ACR-EULAR collaborative initiative. Arthritis Rheum 2013;65:2737-2747.
19. Herbert MK, Stammen-Vogelzangs J, Verbeek MM, et al. Disease specificity of autoantibodies to cytosolic 5'-nucleotidase 1A in sporadic inclusion body myositis versus known autoimmune diseases. Ann Rheum Dis 2016;75:696-701.

20. Badrising UA, Schreuder GMT, Giphart MJ, et al. Associations with autoimmune disorders and HLA class I and II antigens in inclusion body myositis. Neurology 2004; 63:2396-2398.

21. Albayda J, Khan A, Casciola-Rosen L, Corse AM, Paik JJ, Christopher-Stine L. Inflammatory myopathy associated with anti-mitochondrial antibodies: a distinct phenotype with cardiac involvement. Semin Arthritis Rheum 2018;47: $552-556$.

22. Maeda MH, Tsuji S, Shimizu J. Inflammatory myopathies associated with antimitochondrial antibodies. Brain J Neurol 2012;135:1767-1777.

23. Pietinalho A, Tukiainen P, Haahtela T, Persson T, Selroos O; Finnish Pulmonary Sarcoidosis Study Group. Early treatment of stage II sarcoidosis improves 5-year pulmonary function. Chest 2002;121:24-31.

24. Benveniste O, Guiguet M, Freebody J, et al. Long-term observational study of sporadic inclusion body myositis. Brain J Neurol 2011;134:3176-3184. 


\section{Neurology}

\section{Granulomatosis-associated myositis: High prevalence of sporadic inclusion body myositis}

Yannick Dieudonné, Yves Allenbach, Olivier Benveniste, et al.

Neurology published online December 27, 2019

DOI 10.1212/WNL.0000000000008863

\section{This information is current as of December 27, 2019}

Updated Information \& Services

Subspecialty Collections

Permissions \& Licensing

Reprints including high resolution figures, can be found at: http://n.neurology.org/content/early/2019/12/27/WNL.0000000000008 863.full

This article, along with others on similar topics, appears in the following collection(s):

All Neuromuscular Disease

http://n.neurology.org/cgi/collection/all_neuromuscular_disease Autoimmune diseases

http://n.neurology.org/cgi/collection/autoimmune_diseases

Muscle disease

http://n.neurology.org/cgi/collection/muscle_disease

Information about reproducing this article in parts (figures,tables) or in its entirety can be found online at:

http://www.neurology.org/about/about_the_journal\#permissions

Information about ordering reprints can be found online:

http://n.neurology.org/subscribers/advertise

Neurology ${ }^{\circledR}$ is the official journal of the American Academy of Neurology. Published continuously since 1951, it is now a weekly with 48 issues per year. Copyright @ 2019 American Academy of Neurology. All rights reserved. Print ISSN: 0028-3878. Online ISSN: 1526-632X.

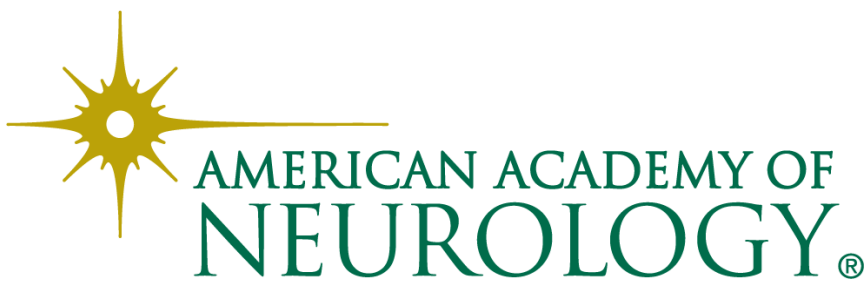

